
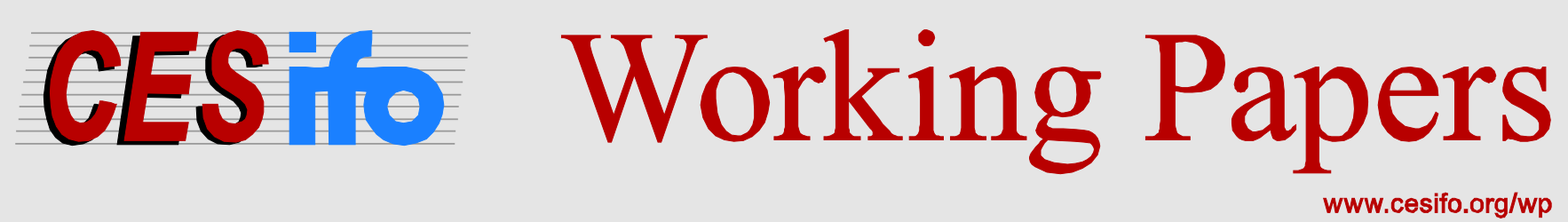

\title{
Estimating Fluctuations in Oil and Gas Investment
}

\author{
Roy Endré Dahl \\ Petter Osmundsen
}

\author{
CESIFO WORKING PAPER NO. 5011 \\ CATEGORY 9: RESOURCE AND ENVIRONMENT ECONOMICS \\ OCTOBER 2014
}

An electronic version of the paper may be downloaded

- from the SSRN website:

- from the RePEc website:

- from the CESifo website:

WwW.SSRN.com

www.RePEc.org

www.CESifo-group.org/wp

\section{CESifo}




\title{
Estimating Fluctuations in Oil and Gas Investment
}

\begin{abstract}
Governments in extraction countries are anxious to estimate expected investment in development projects, since they represent an essential element of the macro economy. The overall level of activity is also crucial to oil companies, since the macro picture affects cost levels, the supplies market and recruitment opportunities. The paper outlines factors that explain fluctuations in investment in petroleum projects on the Norwegian continental shelf.

JEL-Code: M210, L710, F210, E320.
\end{abstract}

Keywords: investments, oil industry, cost overruns, megaprojects, business cycles.

\author{
Roy Endré Dahl* \\ Department of Industrial Economics and \\ Risk Management \\ University of Stavanger \\ Norway-4036 Stavanger \\ roy.e.dahl@uis.no
}

\author{
Petter Osmundsen \\ University of Stavanger \\ Norway-4036 Stavanger \\ petter.osmundsen@uis.no
}

*corresponding author

Thanks are due to a number of specialists in petroleum-related government agencies, the oil industry and the supplies sector for useful suggestions and comments. Thanks to the Research Council of Norway (Petrosam 2) for funding. 


\section{Introduction}

Megaprojects, like projects often undertaken by the petroleum industry, tend to be expensive and often more expensive than their initial budget. Flyvbjerg et al. (2003) consider public megaprojects and show that while these projects often is argued to provide jobs, economic gain, environmental benefits and public services, most megaprojects ends up with considerable cost overruns and only partially fulfilling their objectives. When considering a megaproject they find that optimism bias and strategic misrepresentation provide poor decision basis. Consequently, overoptimistic projects are chosen due to their underestimated costs and overestimated revenues, like an inverted Darwinism. Moreover, since a megaproject is big by definition, it is difficult to cancel after it has been initiated due to already heavy investments, like the principle of inertia derived from Newton's first law. As such, even substantial cost overruns are ignored in order to complete the project. Some of these characteristics found when considering public megaprojects, may also be true for megaprojects in the petroleum industry. E.g. while it is possible to end a project unfinished, most projects are completed despite cost overruns. Moreover, in Norway where the government is heavily invested in the exploration through tax depreciations and later high tax revenues, the state's direct financial participation in the perceived most profitable fields, and in Statoil through ownership, all projects on the Norwegian continental shelf are, to some extent, public.

The oil and gas industry provides growth opportunities in extraction countries as a result of major investment in infrastructure and production facilities. The scale of petroleum projects will secure job opportunities directly and indirectly for decades and as such government and society in general need to facilitate the industry and provide the necessary basis. Politically, this creates some of the same challenges as seen in Flyvbjerg et al. (2003) when considering different approaches to extracting an exhaustible resource to maximize social benefits. Short-term and long-term considerations need careful balancing in order to ensure beneficial development and to avoid pro-cyclicality. For instance while Norway, Saudi Arabia and Brazil all have substantial reserves and production, the three governments have different approaches to setting up the industry and revenue collection for society. Still, petroleum projects have common features whether undertaken in Europe or the Middle East, and as such our study using Norwegian data can provide international knowledge.

According to Merrow (2011, 2012), the petroleum industry is particularly poor at delivering at budget and on time. The success rate in the petroleum industry is only $25 \%$ and Merrow (2012) argues that one key reason is the petroleum industry's high turnover in project leadership. Moreover, Mishra (2014) at IPA, indicates that projects undertaken on the Norwegian continental shelf (NCS) perform worse than comparable projects undertaken in the Gulf of Mexico (GoM). Their report shows that 
Norwegian projects less frequently use repeated designs, which are standardized design used in several projects. In addition, the report stresses that it is necessary to complete the Front End Engineering Design (FEED-work), in order to increase the probability of success and cost efficiency. Finally, the turnover is higher on the NCS than in the GoM, with 6 out of 10 project leaders being replaced during the project lifespan on the NCS, compared to 2 out of 10 in the GoM. This provides even more incentives to study the investment progress on Norwegian projects.

A report written on behalf of the Norwegian Petroleum Directorate (2013), considers 5 megaprojects $^{2}$ on the Norwegian continental shelf. The findings in the report were compared to NOU (1999), a similar report produced by the Investment Committee in 1998. Although there are 15 years between the two reports, the conclusions are similar. First, cost overruns are often identified in early phases. Second, underestimating uncertainty and unrealistic ambitions created too optimistic estimates for project cost and progress. This, together with insufficient time for pre-engineering is the main reasons for the cost overruns experienced on NCS according to the two reports.

License holders/operators on the Norwegian continental shelf are required to provide a yearly report on actual cost and cost estimates for development projects to the Ministry of Petroleum and Energy. In this paper we investigate projects going back to 2000 , compare their original budget size to later adjustments, and outlines future analysis of deviations While there are several reasons to make adjustments to the initial budget, our findings indicate that most projects is finished at a higher cost than predicted and in addition we find that bigger projects seem to have a higher relative cost overrun compared to smaller projects. Considering the increasing complexity of upcoming projects, this may suggest that future projects will continue to experience substantial cost overruns.

Existing empirical work on oil investment on the Norwegian continental shelf relates only to exploration. It has focused on the relationship between drilling activity and such investment drivers as the oil price, recoverable resources and licensed acreage (see, for example, Mohn and Osmundsen, 2008; 2011 and Mohn 2008). Drilling activity is modelled in terms of an error-correction model, where investment drivers are assumed to be uninfluenced by drilling activity. Using the concept of co-integration (Engle and Granger, 1987; Hendry and Juselius, 2000), the error-correction model has the benefit of explicitly separating short-run adjustments from the long-run equilibrium relationships.

At the research group in industrial economics at the University of Stavanger we have started a four year research project on productivity and cost overruns in Norwegian offshore development

\footnotetext{
${ }^{2}$ Skarv, Yme, Valhall Videreutvikling (VRD), Tyrihans and Gjøa.
} 
projects. In this paper we outline this research. We will examine how investment in oil and gas development projects depends on various investment drivers. This requires multivariate modelling, whereby dynamics and interactions between several variables are analysed simultaneously. This will allow us to capture important interactions between total investments, for example, recoverable resources and policy variables. The multivariate extension of the error-correction model is referred to in the economics literature as the vector error correction model (eg, Johansen, 1988). This model representation is an extension of the vector autoregressive models, which have a rich history in macro-economic modelling (eg, Sims, 1980). Carefully separating investment variables determined within the investment model from exogenous investment determinants will allow us to formulate a full structural representation of oil investments. The impact of oil prices, for example, on total investment can then be analysed using conventional statistical tools such as impulse response analysis and variance decompositions. This allows us to address important questions such as how total oil investment responds to oil price movements or other investment drivers, both in the short term and in the long run.

In section 2 we review petroleum activity on the Norwegian continental shelf and in section 3 we present project cost data provided by the Ministry of Petroleum and Energy from 2000 until 2013. In section 4 we consider the timing of cost overruns and in section 5 we present a set of factors that may explain the fluctuations in investment in the petroleum sector since 2000 and explain our research design. The factors include regional factors like population, immigration, unemployment, drilling activity and production on NCS and global factors like the price of oil in USD/bbl, price of steel, rig rates and global oil and gas production.

\section{Petroleum projects on the Norwegian continental shelf (NCS)}

The Norwegian Continental Shelf (NCS) has seen oil and gas production since the early 1970s, with the first oil drilling at the Ekofisk field in 1971. Figure 1 shows the yearly oil and gas production on NCS, and since 1971 oil and gas output from NCS increased steadily until it peaked in 2004 at 264000 million Sm3 of oil equivalents (o.e.). Recent years have seen a reduction and in 2013 the production was only 215000 million Sm3 of o.e.. In particular, the reduction has come from the output of oil, dropping from 181000 million Sm3 in both 2000 and 2001 to 85000 million Sm3 in 2013. 


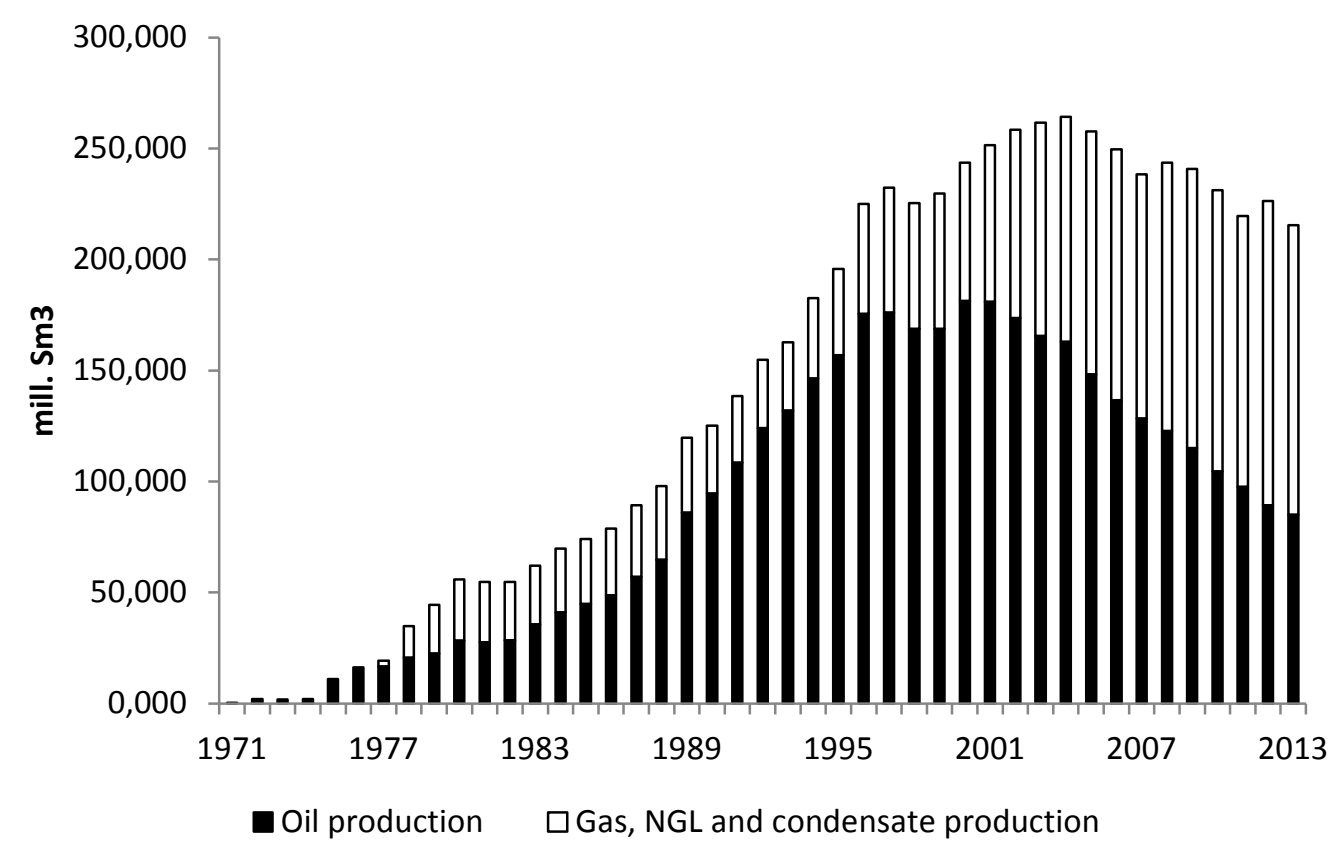

Figure 1 - Yearly oil and gas production on NCS in mill. Sm3

The high production seen on NCS since the 70s created an economic boost in the Norwegian economy and the projects initiated in the oil and gas industry have provided huge benefits to the Norwegian society. As oil production was declining in the beginning of the new millennium, the government added extra incentive for oil investment with advanced tax deductions in 2005 . This provided immediate tax deduction of exploration expenses and immediate repayment of negative tax positions, making it easier for smaller companies to take on exploration projects. As a result, exploration activity increased. Several new companies were established and many existing companies put up business in Norway to take advantage of the new tax regime in the search for new oil and gas fields.

\section{Statistical analysis of Norwegian oil projects}

The analysis is based on data collected from the Norwegian Ministry of Oil and Energy. Preparation of PDOs and PIOs form the basis for the Ministry of Petroleum and Energy's (MPE's) approval of plans for development and operation (PDOs) and special permits for installation and operation (PIOs), pursuant to the Petroleum Act. ${ }^{3}$ For our empirical analysis we will use PDO/PIO-estimates for the interval 2000-2013. The cost-estimates have been inflation adjusted to 2000. In total 96 projects are included, starting with 8 projects in 2000 and ending with 27 projects in 2013, see Table 1. Figure 2

\footnotetext{
${ }^{3}$ http://www.npd.no/global/engelsk/5\%20-\%20rules\%20and\%20regulations/guidelines/pdo-pioguidelines 2010.pdf
} 
shows that on average, project size has been increasing throughout the sample period, from 6.5 MNOK to almost 20 MNOK in 2013. This increase can also be seen in the rising share of mega projects in Table 1 and Figure 3; the cost estimates and actual cost are rising.

Table 1 - number and average cost of projects. Megaprojects >= 15000 MNOK

\begin{tabular}{ccccccccccccccc} 
& $\mathbf{2 0 0 0}$ & $\mathbf{2 0 0 1}$ & $\mathbf{2 0 0 2}$ & $\mathbf{2 0 0 3}$ & $\mathbf{2 0 0 4}$ & $\mathbf{2 0 0 5}$ & $\mathbf{2 0 0 6}$ & $\mathbf{2 0 0 7}$ & $\mathbf{2 0 0 8}$ & $\mathbf{2 0 0 9}$ & $\mathbf{2 0 1 0}$ & $\mathbf{2 0 1 1}$ & $\mathbf{2 0 1 2}$ & $\mathbf{2 0 1 3}$ \\
\hline \# megaprojects & 1 & 3 & 3 & 3 & 4 & 3 & 5 & 7 & 7 & 5 & 5 & 8 & 11 & 15 \\
\# other projects & 7 & 15 & 14 & 17 & 15 & 19 & 17 & 17 & 15 & 12 & 10 & 14 & 13 & 12 \\
\hline Total projects & $\mathbf{8}$ & $\mathbf{1 8}$ & $\mathbf{1 7}$ & $\mathbf{2 0}$ & $\mathbf{1 9}$ & $\mathbf{2 2}$ & $\mathbf{2 2}$ & $\mathbf{2 4}$ & $\mathbf{2 2}$ & $\mathbf{1 7}$ & $\mathbf{1 5}$ & $\mathbf{2 2}$ & $\mathbf{2 4}$ & $\mathbf{2 7}$ \\
$\begin{array}{c}\text { Average cost } \\
\text { (thousand MNOK) }\end{array}$ & 6.5 & 4.1 & 4.5 & 4.2 & 8.5 & 7.3 & 8.3 & 10.6 & 10.8 & 10.5 & 13.0 & 14.0 & 16.1 & 20.0
\end{tabular}

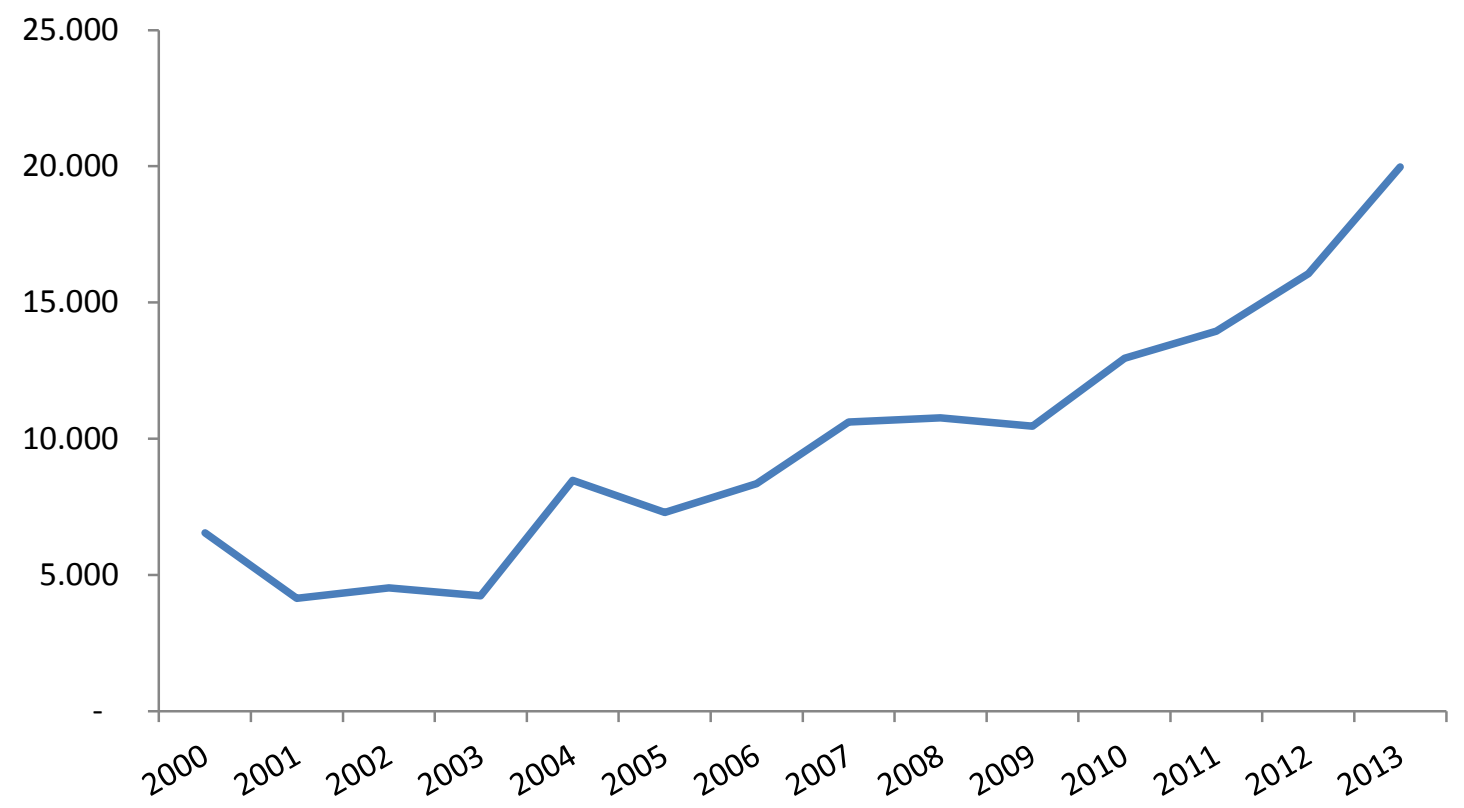

Figure 2 - Average cost estimate in MNOK 


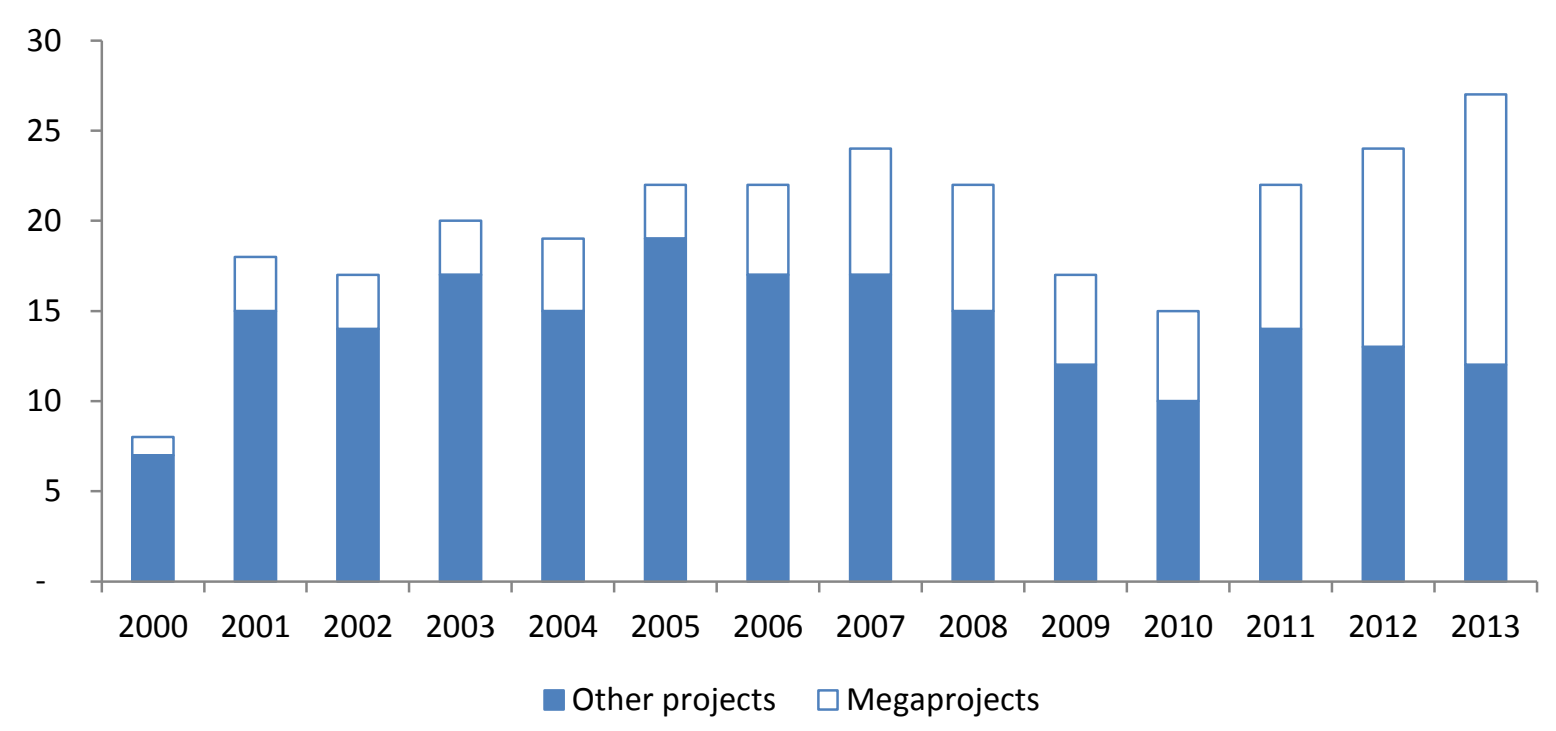

Figure 3 - Number of projects per year. Megaprojects $>=15000$ MNOK

In Table 2 and Figure 4 we study cost overruns by comparing the original cost estimate with adjusted cost estimates, giving us a timeline where we identify when overruns were reported as well as an overview over total investments over time.

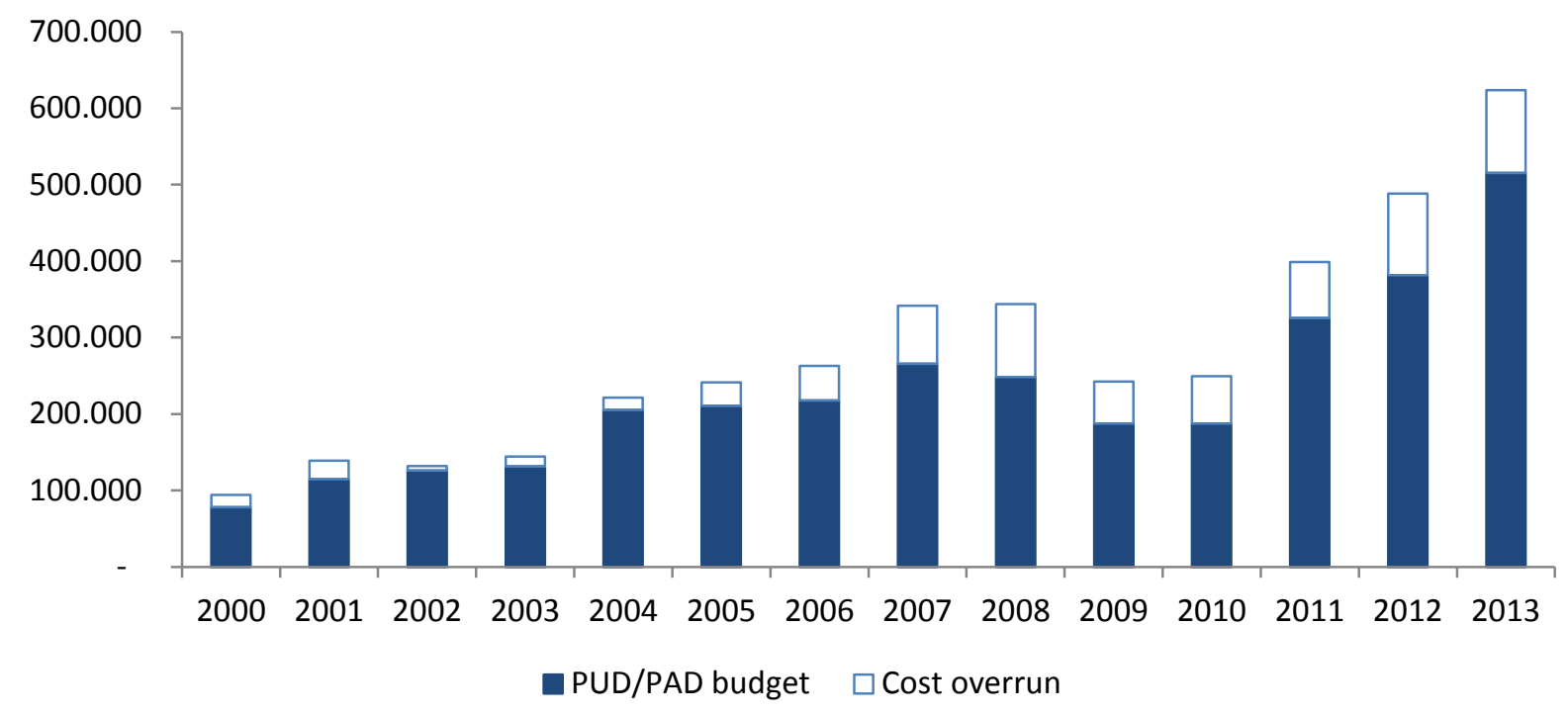

Figure 4 - Adjusted PUD/PAD-estimates compared to original PUD/PAD-estimate

Table 2 - PUD/PAD-estimates and cost overruns in thousand MNOK.

\begin{tabular}{lllllllllllllll} 
& $\mathbf{2 0 0 0}$ & $\mathbf{2 0 0 1}$ & $\mathbf{2 0 0 2}$ & $\mathbf{2 0 0 3}$ & $\mathbf{2 0 0 4}$ & $\mathbf{2 0 0 5}$ & $\mathbf{2 0 0 6}$ & $\mathbf{2 0 0 7}$ & $\mathbf{2 0 0 8}$ & $\mathbf{2 0 0 9}$ & $\mathbf{2 0 1 0}$ & $\mathbf{2 0 1 1}$ & $\mathbf{2 0 1 2}$ & $\mathbf{2 0 1 3}$ \\
\hline PUD budget & 78 & 115 & 126 & 132 & 205 & 211 & 218 & 266 & 248 & 187 & 187 & 326 & 381 & 516 \\
Cost overrun & 16 & 24 & 6 & 13 & 16 & 31 & 45 & 76 & 95 & 55 & 62 & 73 & 107 & 108 \\
\hline \%-overrun & $21 \%$ & $21 \%$ & $5 \%$ & $10 \%$ & $8 \%$ & $15 \%$ & $21 \%$ & $29 \%$ & $38 \%$ & $29 \%$ & $33 \%$ & $22 \%$ & $28 \%$ & $21 \%$ \\
\hline
\end{tabular}


Further, in Figure 5 we identify at what time projects were initiated, and compare their final cost (last known estimate in PUD/PAD). This reveals that projects initiated before the financial crisis had the largest cost overruns. Especially, projects started in 2004 and 2007 experienced major overruns. These overruns are to a large extent caused by a limited number of projects as displayed in Table 3, where the biggest overruns are presented. With 5 of the top 15 overruns initiated in 2007 (Valhall, Skarv, Yme, Gjøa and Vega) and the biggest overrun registered in 2004 (Ormen Lange). We need to note that some of the more recent projects may still experience overruns since they have not been finished. Indeed, projects initiated in 2013 have no overruns so far since the last PUD/PAD-estimates are from 2013 and are therefore left out of Figure 5.

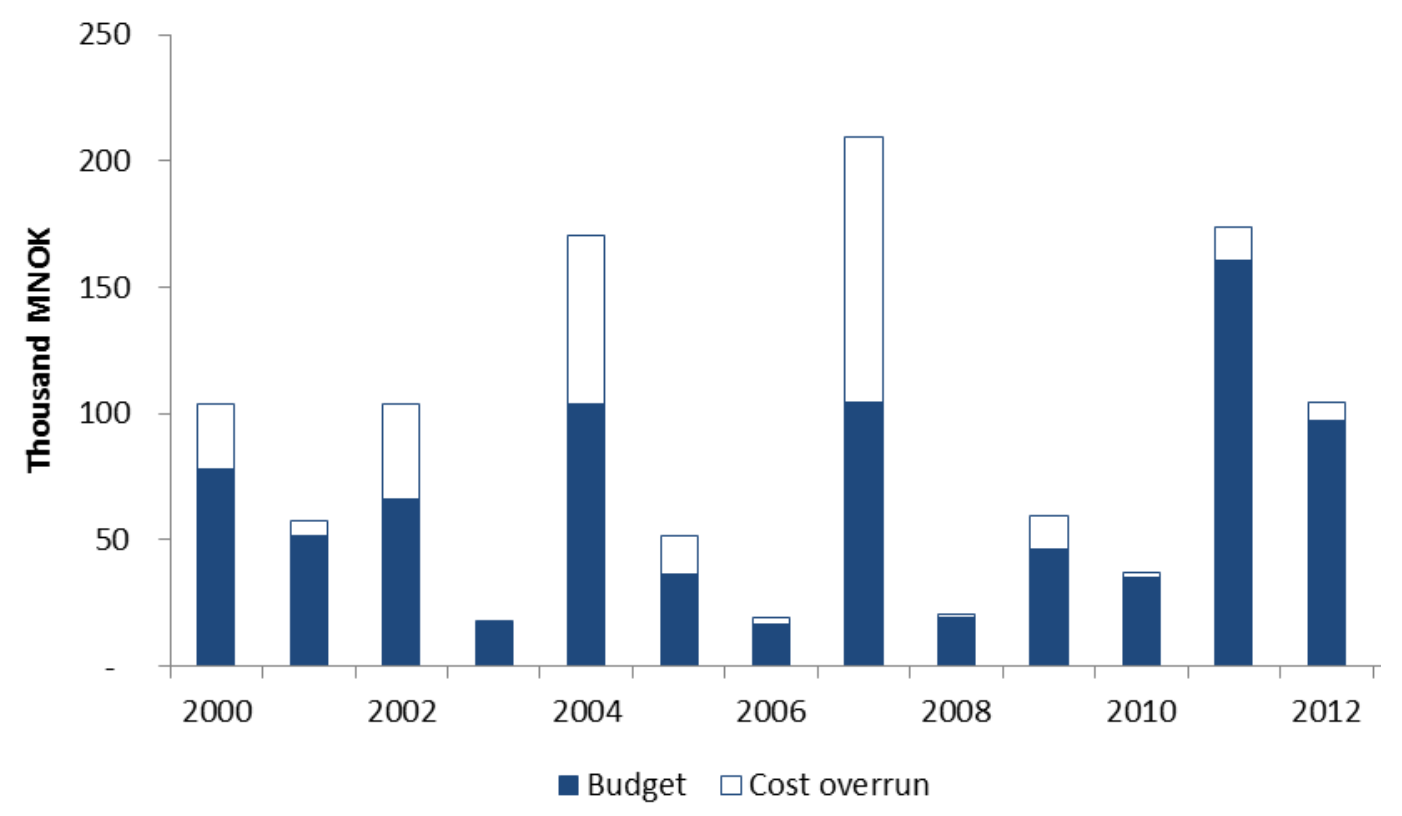

Figure 5- PUD/PAD-estimates and cost overruns in thousand MNOK.

The information found in Figure 5 can also be compared to the oil price. In Figure 6 it is evident that the largest cost overruns were experienced in projects originating from 2007, when prices almost doubled from around 50 USD/bbl to around 95 USD/bbl. Projects from 2007 include Valhall, Skarv, Yme, Gjøa and Vega, all of which experienced severe cost overruns, see Table 3. Only 2004 experienced similar cost overruns as seen in 2007, with Ormen Lange and Alvheim being responsible for the majority of the overruns. During 2004 the prices increased from 34 USD/bbl to a maximum of around $55 \mathrm{USD} / \mathrm{bbl}$.

Contrary, projects initiated in the year after the financial crisis and the extreme price drop from 134 USD/bbl to below $40 \mathrm{USD} / \mathrm{bbl}$ have experienced only small cost overruns. For the most recent years this may be a consequence of the fact that the projects are still in their early years, but projects 
started in 2008-2010 should at this point of time have experienced some of the problems often leading to cost overruns. Oil price increase leads to cost pressure as the activity levels increase, both locally and globally. To ascertain the lag structure of the oil price effect is part of our research project.

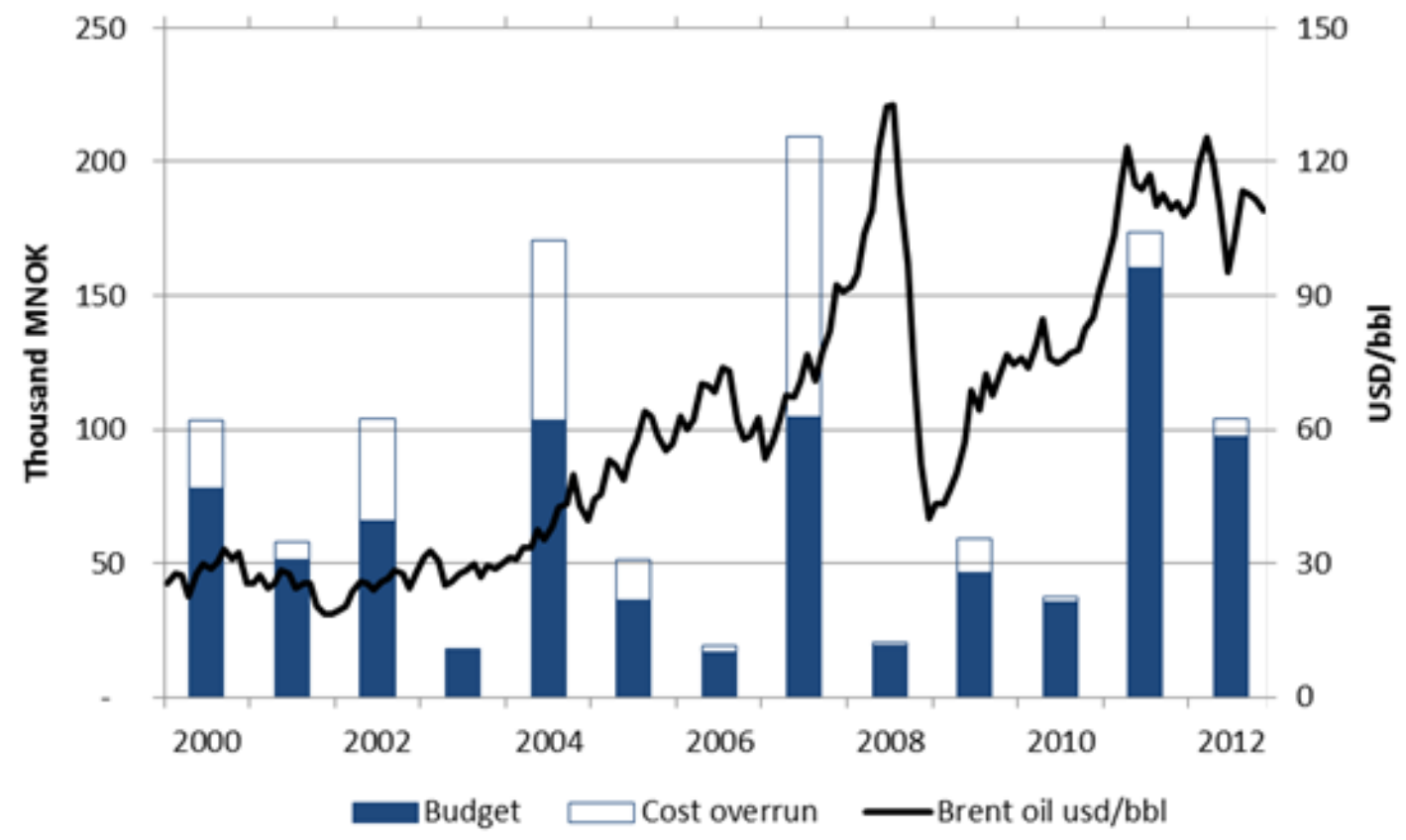

Figure 6 - PUD/PAD-estimates and cost overruns in thousand MNOK. Oil price in USD/bbl.

Table 3-15 projects with largest cost overrun in the dataset. All numbers in thousand MNOK.

\begin{tabular}{|lrrrrr|}
\hline Project & $\begin{array}{r}\text { Index } \\
\text { year }\end{array}$ & $\begin{array}{r}\text { PUD/PAD- } \\
\text { estimate }\end{array}$ & $\begin{array}{r}\text { Last } \\
\text { estimate }\end{array}$ & $\begin{array}{r}\text { Cost } \\
\text { overrun }\end{array}$ & (in \%) \\
\hline Ormen Lange/Langeled & 2004 & 72,6 & 125,0 & 52,4 & $72 \%$ \\
\hline Valhall Videreutvikling & 2007 & 16,1 & 63,1 & 47,1 & $293 \%$ \\
\hline Snøhvit LNG & 2002 & 42,0 & 72,5 & 30,5 & $73 \%$ \\
\hline Skarv & 2007 & 35,5 & 59,9 & 24,4 & $69 \%$ \\
\hline Åsgårdkjeden & 2000 & 39,6 & 57,4 & 17,8 & $45 \%$ \\
\hline Goliat & 2009 & 34,1 & 49,0 & 14,9 & $44 \%$ \\
\hline Yme & 2007 & 4,9 & 17,6 & 12,7 & $259 \%$ \\
\hline Alvheim & 2004 & 8,8 & 20,1 & 11,3 & $128 \%$ \\
\hline Gjøa inkl. Gjøa gassrør & 2007 & 31,7 & 41,3 & 9,7 & $31 \%$ \\
\hline Kristin & 2002 & 17,0 & 23,8 & 6,8 & $40 \%$ \\
\hline Statfjord seinfase & 2005 & 14,9 & 21,6 & 6,7 & $45 \%$ \\
\hline Martin Linge & 2012 & 31,9 & 38,0 & 6,1 & $19 \%$ \\
\hline Vega og Vega Sør & 2007 & 7,0 & 12,4 & 5,5 & $79 \%$ \\
\hline Valemon & 2011 & 24,2 & 28,0 & 3,8 & $16 \%$ \\
\hline Valhall vanninjeksjon & 2001 & 4,9 & 8,5 & 3,6 & $75 \%$ \\
\hline
\end{tabular}




\section{Timing of cost overruns}

In Figure 7 and Figure 8 we have tried to identify when the cost overrun is typically experienced for a project. It is evident from Figure 7 that cost overruns are accumulated throughout the project lifetime. Moreover, Figure 8 shows that the size of the cost overrun in percentage is increasing with the number of years since project start. While the cost overrun is on average $6 \%$ in year 1 , it increases to around $12 \%$ in both the $3^{\text {rd }}$ and $4^{\text {th }}$ year. From these figures it is evident that both the accumulated cost overrun and the yearly cost overrun increases with the age of the project, with projects lasting more than 4 years having the biggest cost overruns. From Table 4 one should note that the number of projects is decreasing with the number of years from budget year. Indeed, we have only 2 projects with 6 years of PUD/PAD-estimates, Skarv and Valhall, which both have experienced extreme overruns. Still, this indicates that projects which have recently been initiated may still experience substantial overruns.

From project management experience, there are several reasons for increasing cost overruns over time. The first part of the cost overrun is concealed, as it is covered by the funds set aside in the budget for contingency. Thereafter, we have a phase where the project manager or the company would like to conceal a cost overrun, in the hope that they can recoup the increased cost by increased productivity. Finally, towards the end of the project cost escalate as it is more difficult to maintain control over a large project and since bargaining power may shift over to the suppliers if the oil company becomes impatient.

Projects that experience cost overruns are often also delayed. This is a relationship that we will examine in our research project.

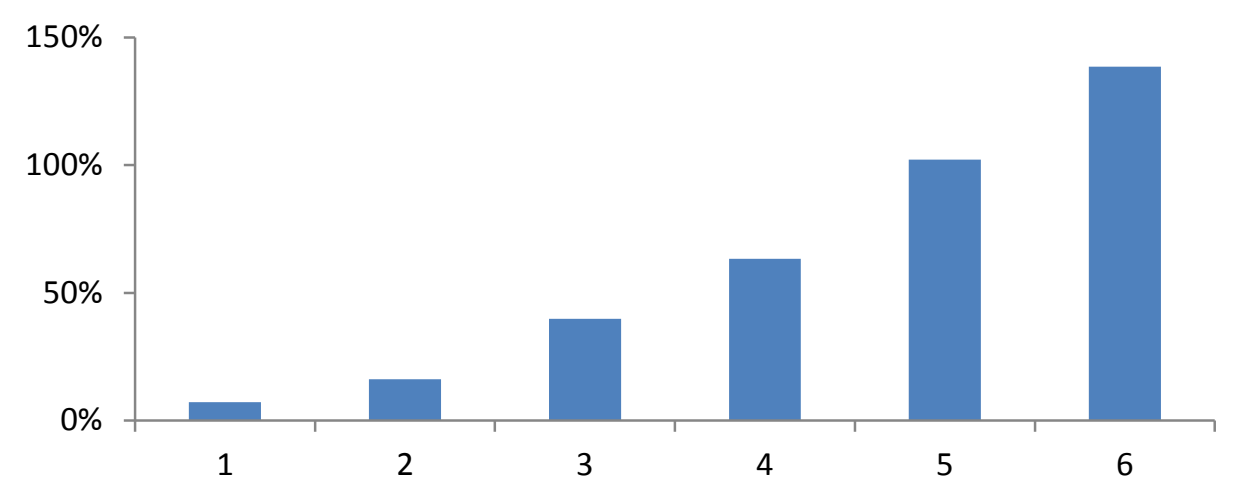

Figure 7 - Total cost overrun $\mathbf{n}$ years after initial PUD-acceptance 


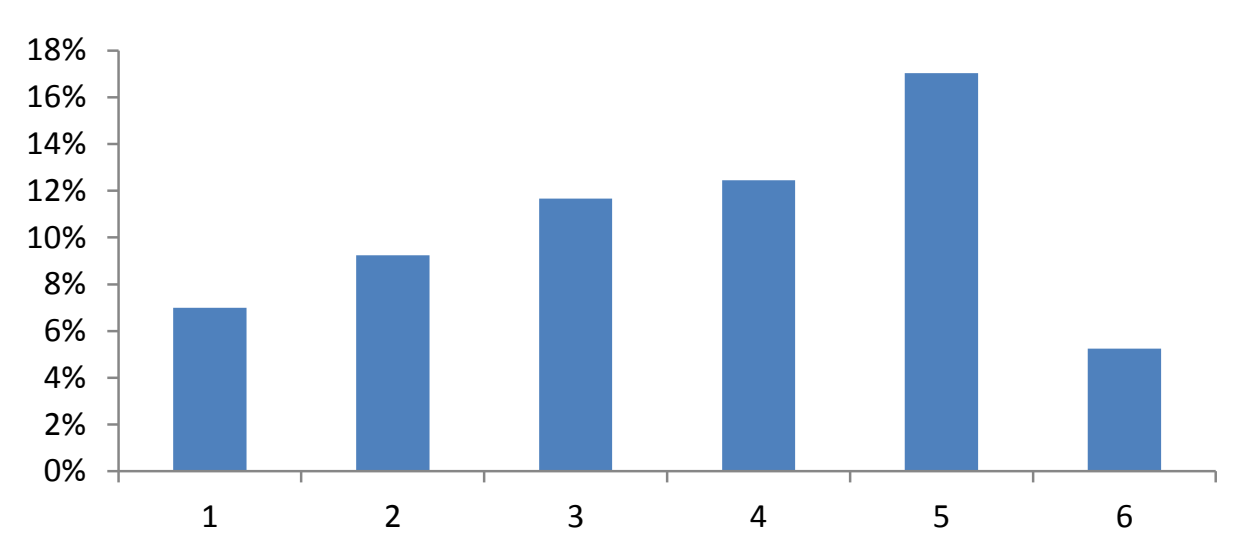

Figure 8 - Yearly cost overrun $\mathbf{n}$ years after initial PUD-acceptance

Table 4 - Number of projects and average cost overrun $\mathbf{n}$ years after initial PUD-acceptance

\begin{tabular}{|lrrrrrrr|}
\hline Years after budget & $\mathbf{0}$ & $\mathbf{1}$ & $\mathbf{2}$ & $\mathbf{3}$ & $\mathbf{4}$ & $\mathbf{5}$ & $\mathbf{6}$ \\
\hline Number of projects & 95 & 82 & 57 & 29 & 13 & 5 & 2 \\
\hline Average total cost overrun & - & $7 \%$ & $16 \%$ & $40 \%$ & $63 \%$ & $102 \%$ & $138 \%$ \\
\hline Average yearly cost overrun & - & $7 \%$ & $9 \%$ & $12 \%$ & $12 \%$ & $17 \%$ & $5 \%$ \\
\hline
\end{tabular}

\section{Research design}

This section outlines vital issues for research design of cost performance in development projects, first of which is the issue of normalisation. To make costs comparable across projects we need a common denominator. A value figure would be welcome from an economics perspective, but we do not see any likely candidates. At any rate, to evaluate performance in developing oil and gas fields, we need to isolate development project performance and filter out the effect of petroleum prices and performance in other dimensions, like quality of subsurface interpretations. A standard metric in construction industry is cost per tonne of the installation constructed. This is one type of measurement of the productivity in construction, and it is also used in cost analysis. However, as we do recognise the need for compartementalisation and thus use a metric unique to construction, we do find this metric as being too far from the value creation of an oil company. The main objection is that cost per tonne does not capture the effort to keep the weight of the facilities down. This is partly a function of engineering (which is often part of the delivery, by use of Engineering, Procurement, Construction contracts; EPC), and partly a result of the quality of the work performance and the steel quality applied. 
Development relative to proven petroleum reserves is another possible metric. It makes economic sense and it is based on data that is available. As for all such metrics, there may also be drawbacks. Two fields with the same level of reserves can be developed with different development concepts that affect the speed at which the resources are extracted. A solution emphasising higher extraction speed is often more costly and therefore not directly comparable. Note that too high focus on speed may reduce the amount of the recoverable reserves (reduced extraction rate).

In EPC-contracts, oil companies do not specify details of engineering, but instead set functional requirements. A relevant example is capacity. A production facility, e.g., should have a certain plateau processing and production capacity. This metric would capture the issue of extraction speed. Common for the metrics that relate development costs to reserves and plateau production is that they are able to account for changes in reserves and production capacity during project execution. Oil companies continue analysing the reservoirs and optimal depletion strategies after engineering and even construction have started, and this may lead to changes in reserve estimation or production and processing capacity specifications during project execution. Such late changes are often very costly but can at the same time generate considerable value in terms of improved reservoir exploitation. Thus, part of the cost overruns is in some projects justified. Moving metrics that relates to reserves or capacity are able to capture these trade-offs. However, such dynamic analyses are data demanding.

This far, we have discussed the choice of performance measure, i.e., the left-hand side variable of the econometric specification. We may analyse and explain the development in the metric over time. Alternatively, we may examine the deviation from the planned metric, i.e., analyse and explain the normalised cost overrun.

We now turn to the factors that may explain variation in performance. To enhance comparison between projects, one might want to make use of objective field specific characteristics that are known to affect development costs. Examples are water depth and drilling depth. The size of the project is also relevant, although more complex as it changes over time, since large projects are known to be harder to manage and since they may crown out local factor markets and generate price increases. Another relevant issue is the expected mix of oil and natural gas that can be recovered. Yet another distinction is between fields that are developed on a stand-alone basis and fields that make use of existing infrastructure, e.g., tie-in solutions. This can be captured by an indicator variable. These technical parameters should be supplemented by economic parameters. These can be represented by a set of regional factors (GDP growth, rig rates, unemployment, overall NCS investment level, and overall drilling and production activity) and a set of global factors (cost indexes 
for upstream petroleum industry, interest rate, GDP growth, price of oil in USD/bbl, price of steel, and global oil and gas production). By identifying both regional and global factors we want to study the dynamics on both levels simultaneously. This requires multivariate modelling, and by extending the vector autoregressive model (Sims, 1980) by using VECM, we can formulate a full structural representation of oil investments. 


\section{References}

Engle, R. F., and Granger, C. W. J. (1987), "Co-integration and Error Correction: Representation, Estimation, and Testing", Econometrica vol. 55 (2), 251-76.

Flyvbjerg, B., Bruzelius, N. and Rothengatter, W. (2003), "Megaprojects and Risk: An Anatomy of Ambition", Cambridge University Press.

Hendry, D. F., and Juselius K. (2000), "Explaining Cointegration Analysis: Part 1", The Energy Journal vol. 21(1), 1-42.

Johansen, S. (1988), "Statistical Analysis of Cointegration Vectors", Journal of Economic Dynamics and Control vol. 12, 231-254.

Merrow, E. W. (2011), "Industrial Megaprojects: Concepts, Strategies and Practices for Success.", John Wiley \& Sons.

Merrow, E. W. (2012), "Oil and Gas Industry Megaprojects: Our recent track record.", Oil and Gas Facilities vol. 4, $38-42$.

Mishra, N. (2014). "On budget - on time", Conference Speech at The Norwegian Petroleum Directorate.

Mohn, K (2008), "Efforts and Efficiency in Oil Exploration: A Vector Error-Correction Approach", Energy Journal 29, 4, 53-78.

Mohn, K. and P. Osmundsen (2011), "Asymmetry and uncertainty in capital formation: an application to oil investment", Applied Economics, Volume 43, Issue 28, November 2011, 4387-4401.

Mohn, K. and P. Osmundsen (2008), "Exploration economics in a regulated petroleum province: The case of the Norwegian continental shelf", Energy Economics 30, 303-320.

Norwegian Petroleum Directorate (2013), "Evaluation of projects implemented on the Norwegian shelf", Norwegian Petroleum Directorate.

NOU (1999), “NOU1999:11 Analyse av investeringsutviklingen på kontinentalsokkelen. (Analysis of the investment development on the continental shelf)"

Sims, C.A. (1980), "Macroeconomics and Reality", Econometrica vol. 48, 1-48. 